\title{
THE USE OF DENOSUMAB IN GIANT CELL TUMORS IN THE SACRUM
}

\author{
O USO DE DENOSUMAB EM TUMORES DE CÉLULAS GIGANTES NO SACRO
}

\section{EL USO DE DENOSUMAB EN EL TUMOR DE CELULAS GIGANTES EN EL SACRO}

\author{
Pedro luis Bazán, ${ }^{1,2}$ Renata Di Falco, ${ }^{3}$ Alvaro Enrique Borri, 1,2 Martín Medina, ${ }^{1,2}$ Nicolás Maximiliano Ciccioli, ${ }^{2,4}$ Sergio Danielle ${ }^{5}$ \\ 1. Universidad Nacional de La Plata, Faculty of Medical Sciences, La Plata, Buenos Aires, Argentina. \\ 2. Hospital Italiano La Plata, Spine Pathology Unit, La Plata, Buenos Aires, Argentina. \\ 3. Hospital Municipal de Agudos Leonidas Lucero, Bahía Blanca, Buenos Aires, Argentina. \\ 4. Clínica Pueyrredon, Mar del Plata, Buenos Aires, Argentina. \\ 5. Oncology Service, Hospital Italiano La Plata, Buenos Aires, Argentina.
}

\begin{abstract}
Giant Cell Tumor (GCT), a benign tumor with local aggression, corresponds to $5 \%$ of primary tumors. Fifteen percent of these are located in the sacrum. En bloc resection is an effective treatment, but when it cannot be performed, Denosumab may be indicated as an alternative treatment. The objectives of this work are: to justify the indication; determine the best dose and time of use; and recognize the need for posttreatment surgery. Methods: A systematic search of clinical trials. Twenty-five articles were selected, ten of which met the inclusion criteria. The use of Denosumab is justified in advanced stages, with a dose of $120 \mathrm{mg}$ administered subcutaneously, every 7 days in the first month and then maintained every 4 weeks, for 2.5 to 13 months. Adverse events are mild and can be observed in $84 \%$ of patients. With Denosumab, surgery may be less aggressive or even unnecessary. The bibliography justifies the indication of Denosumab in advanced stages of GCT, with a dose of $120 \mathrm{mg}$ administered subcutaneously; there is no consensus as to the maintenance dose, which is a weekly dose in the first month and then every four weeks for 2.5 to 13 months. Complications are frequent but mild. Level of evidence III; Systematic review.
\end{abstract}

Keywords: Giant Cell Tumor of Bone; Sacral Region; Denosumab; Complications.

\section{RESUMO}

O tumor de células gigantes (TCG), um tumor benigno com agressão local, corresponde a 5\% dos tumores primários. Quinze por cento desses estão localizados no sacro. A ressecção em bloco é um tratamento eficaz, mas quando não pode ser realizada, o Denosumabe pode ser indicado como tratamento alternativo. Os objetivos desse estudo consistem em justificar a indicação; determinar a melhor dose e tempo de uso e reconhecer a necessidade de cirurgia pós-tratamento. Métodos: Foi realizada uma busca sistemática de ensaios clínicos, sendo que foram selecionados 25 artigos, dos quais dez atenderam aos critérios de inclusão. O uso do Denosumabe é justificado em estágios avançados, com uma dose de $120 \mathrm{mg}$ administrada por via subcutânea, a cada 7 dias no primeiro mês e, depois, mantida a cada 4 semanas, durante 2,5 a 13 meses. Os eventos adversos são leves e podem ser observados em 84\% dos pacientes. Com o Denosumabe, a cirurgia pode ser menos agressiva ou nem necessária. A bibliografia justifica a indicação de Denosumabe em estágios avançados do TCG, com dose de 120 mg administrada por via subcutânea; não há consenso quanto à dose de manutenção, a qual é uma dose semanal no primeiro mês e depois a cada quatro semanas durante 2,5 a 13 meses. As complicações são frequentes, porém leves. Nível de evidência III; Revisão sistemática.

Descritores: Tumor de Células Gigantes do Osso; Região Sacral; Denosumabe; Complicações.

\section{RESUMEN}

El tumor de células gigantes (TCG), un tumor benigno con agresión local, corresponde a 5\% de los tumores primarios. Quince por ciento de éstos están localizados en el sacro. La resección en bloque es un tratamiento eficaz, pero cuando no puede ser realizada, el Denosumab puede ser indicado como tratamiento alternativo. Los objetivos de este estudio consisten en justificar la indicación, determinar la mejor dosis y tiempo de uso, y reconocer la necesidad de cirugía postratamiento. Métodos: Fue realizada una búsqueda sistemática de ensayos clínicos, siendo que fueron seleccionados veinticinco artículos, de los cuales diez atendieron los criterios de inclusión. El uso de Denosumab está justificado en etapas avanzadas, con una dosis de $120 \mathrm{mg}$ administrada por vía subcutánea, a cada 7 días en el primer mes y, después, mantenida a cada 4 semanas, durante 2,5 a 13 meses. Los eventos adversos son leves y pueden observarse en 84\% de los pacientes. Con el Denosumab, la cirugía puede ser menos agresiva o ni necesaria. La bibliografía justifica la indicación de Denosumab en etapas avanzados de TCG, con dosis de 120 mg administrada por vía subcutánea; no hay consenso cuanto a la dosis de mantenimiento, la cual es una dosis semanal en el primer mes y después a cada cuatro semanas durante 2,5 a 13 meses. Las complicaciones son frecuentes, aunque leves. Nivel de evidencia III; Revisión Sistemática.

Descriptores: Tumor Óseo de Células Gigantes; Región Sacra; Denosumab; Complicaciones.

\section{INTRODUCTION}

Giant cell tumors (GCT) account for $5 \%$ of primary tumors with an incidence of 1.3 million per year, which is even higher in patients between 20 and 50 years of age. The areas of the body with most frequent occurrence are the epiphysis of the distal femur, proximal tibia and distal radius. GCTs located in the spine, sacrum or pelvis correspond to $15 \%$ of cases. These are benign tumors with locally aggressive behavior. Two to five present can develop lung 
metastasis, and in less than $1 \%$ of cases, they can affect different locations simultaneously. ${ }^{1}$

In some cases, subchondral fractures or frank cortical destruction and soft tissue extension can be observed. It rarely occurs in skeletally immature patients. The risk of local recurrence varies depending on the treatment modality. Ten percent of patients with recurrent GCT develop pulmonary metastasis. Malignant transformation has been reported spontaneously in the context of previous irradiation, or less frequently, after surgical resection of the tumor.

In GCTs, as in osteoporosis, multiple myeloma and metastatic carcinomas, bone homeostasis is altered. ${ }^{1,2}$ In the case of GCT, giant cell-mediated osteolysis is generated.

Denosumab, a human monoclonal antibody, within the antiresorptive group, is reserved for use in cases of advanced stage GCTs, preventing the typical osteolysis observed in this type of tumor and thus, creating the necessary surgical conditions.

A systematic review of the current bibliography on the use of Denosumab in GCTs was carried out, in order to: justify the indication of the drug; determine the best dose and treatment time to prevent complications; and recognize the need for post-treatment surgery.

\section{METHODS}

A search of the Pubmed and Lilacs databases was performed using the search terms: giant cell tumor, Denosumab, complications and osteonecrosis of the jaw. The search was restricted to clinical trials and articles published in English. Twenty-five articles were selected, ten of which met the inclusion criteria (justification of the indication, dose, treatment time and complications of Denosumab). (Figure 1)

\section{RESULTS}

In relation to the indication of antiresorptive Denosumab for giant cell tumor, Lizz van der Heijden et al. ${ }^{2}$ and Sant Chawla et al. ${ }^{3}$ justify its use in advanced tumors where en bloc resection or even amputation are the only therapeutic options. There is consensus on the dose $(120 \mathrm{mg})$ and the mode of administration, which should be subcutaneous, but not on the interval and time, which vary depending on whether it is a primary or recurrent GCT. (Table 1) 1- $4^{1}$

Chawla et al., ${ }^{3}$ found that $84 \%$ of 282 patients included in their
Table 1. Use of denosumab. Dose/interval/duration.

\begin{tabular}{c|c|c|c}
\hline Author (year) & Dose (mg) & Interval (days) & $\begin{array}{c}\text { Duration } \\
\text { (months) }\end{array}$ \\
\hline Chawla, S (2013) & 120 & 7 & $2.5-13$ \\
\hline Ngl, VY (2014) & 120 & $\begin{array}{c}1 \\
\text { (1st month) and } \\
\text { later 30 }\end{array}$ & \\
\hline Roitman, PD (2017) & 120 & 7 & $3.5-13$ \\
\hline van del Heijden $(2017)^{2}$ & 120 & 7 & $3.5-13$ \\
\hline
\end{tabular}

trial developed some type of adverse effect; $20 \%$ developed arthralgias, $18 \%$ headaches, $17 \%$ nausea, $5 \%$ hypocalcemia, $9 \%$ severe side effects that did not cause death, and $1 \%$ back pain. Raskin et al. ${ }^{5}$ mentioned skeletal pain as the most frequent adverse effect. Osteonecrosis of the jaw is a rare event in patients who use Denosumab, with an incidence of $1-1.7 \%$ of patients. ${ }^{2,3,6,7}$

Denosumab provides an option in the treatment of advanced GCTs for which surgery is contraindicated, or that would result in high morbidity (hemipelvectomy, amputations, neurological disorders), or in cases where it is not possible to resect the entire tumor due to the increased risk of recurrence this entails. Some GCTs do not show progression with the use of Denosumab, sometimes eliminating the need for surgery or achieving an intervention with lower morbidity. ${ }^{2,3,6}$

\section{DISCUSSION}

In the diagnosis of GCT, radiographs and tomography can be used, to identify a lytic, well-circumscribed, non-scleral, eccentric lesion. ${ }^{1,2}$ Magnetic resonance imaging (MRI) is useful for staging and predicting clinical behavior. ${ }^{2}$

Histopathologically, the GCT contains three cell populations: multinucleated giant cells that express the receptor activator of nuclear factor kappa (RANK), monocytes and neoplastic stromal cells that express the ligand RANK (RANKL). It is believed that the pathophysiology is driven by the proliferation of mesenchymal stromal cells that exhibit an immature osteoblastic phenotype. These cells secrete high levels of chemokines that attract circulating monocytes to the site of the injury. Once there, they are initiated to form positive osteoclastic cells, resulting in giant cell-mediated osteolysis. 1,2,4,8,9

The standard treatment of GCT consists of surgical removal of

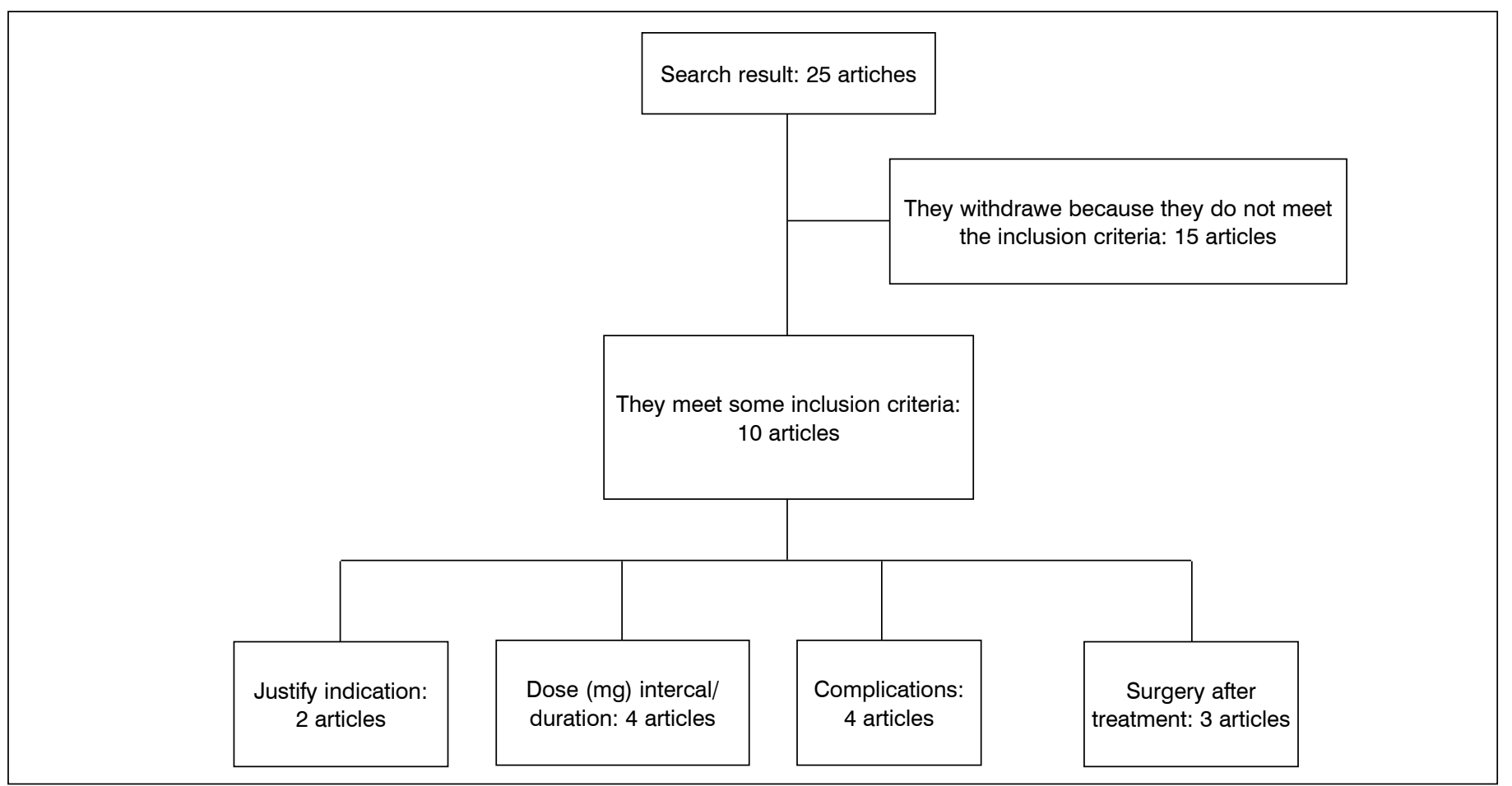

Figure 1. Flowchart of search. 
the tumor, or extensive curettage with or without adjuvants..$^{1,2}$ Surgical treatment in the sacrum is subject to multiple barriers associated with the anatomy and the difficulty of using local coadjuvation. ${ }^{1}$ En bloc resection and radiotherapy should be reserved for patients in whom intralesional surgery and systemic therapy are impossible, as they result in an increased risk of complications such as the development of a sarcoma (3-11\%) and poorer functional outcome in the case of En bloc resections. ${ }^{1,2}$ Serial embolization is used as neoadjuvant therapy to facilitate surgical curettage or resection. Patients with GCT in the sacrum exhibit a favorable initial response; $50 \%$ experience local control. ${ }^{1}$

Most recurrences occur within 2 years of treatment, rates vary from 27 to $65 \%$ for those treated with isolated curettage, $12-27 \%$ if adjuvants such as phenol, PMMC, liquid nitrogen are added to the curettage, and $0-12 \%$ for those which are resected en bloc. Intralesional resection in the sacrum or pelvis has a recurrence rate of $50 \% .{ }^{1}$

Individual parameters that strongly increase local recurrence include: soft tissue extension and spinal or sacral localization.

Denosumab is a human monoclonal antibody inhibitor of RANKL recently registered by the Food and Drug Administration of the United States (FDA) and the European Medicines Agency as a neoadjuvant pharmacological treatment for GCT.2,4,6 It is indicated in patients with advanced GCT. The objectives are to achieve local control and create a surgical situation, inhibiting the recruitment of multinucleated giant cells by the neoplastic stromal cells, thus preventing the osteolysis typically observed in the GCT. If the tumor responds to Denosumab, a partial maturation of the neoplastic stromal cells with the formation of fibrous and osteoid tissue is observed.

Radiographically, a calcified border surrounding the soft tissue and/or a decrease in the size of the lesion can be seen after an average of 3-4 months of drug use, facilitating curettage with local adjuvants in a previously non-curetable GCT.1,2 With longer treatment, a gummy substance is likely to be observed during surgery, which alters the typical macroscopic appearance of the GCT and complicates the complete excision of the tumor by intralesional curettage..$^{2,4}$

After the use of Denosumab, surgery should involve the extension of the entire original tumor in order to reduce the risk of recurrence. ${ }^{2}$

In an open phase II study (NCT00396279), 86\% of patients had an objective response to Denosumab therapy, defined as more than $90 \%$ elimination of giant cells on histological evaluation or without radiographic progression of the lesion. ${ }^{10} \mathrm{~A}$ second, open trial, also phase II, evaluated 282 patients, restoring the high efficiency of Denosumab in GCT. Stable disease was reported in 96\% of GCTs cases without indication of previous curettage after a mean follow-up of 13 months. Most patients had planned surgery with severe morbidity, and with a mean follow-up of 9.2 months, $74 \%$ did not require surgery and $16 \%$ underwent surgery resulting in low morbidity. ${ }^{3}$

The complications and side effects of Denosumab, include pain, fatigue, headache, nausea (18-25\%), hypocalcemia and hypophosphatemia (3\%), and osteonecrosis of the jaw (1-2\%), with a malignant transformation in $1.8 \%$. $^{2,3,4,10}$ The effect on the fetus is unknown, therefore, the use of adequate contraceptives during treatment is recommended with Denosumab. There is no published clinical experience suggesting recurrence after 6-12 months of interruption of treatment. 2,3

The cause of osteonecrosis of the jaw $(\mathrm{ONJ})$ development related to Denosumab suggests that by blocking the RANK-RANKL interaction, the function and survival of monocytes and macrophages would be affected, inhibiting normal bone repair at local microdamage. Dentoalveolar trauma (dental extractions) is the most prevalent and consistent risk to develop it. However, there is limited data on the possible mechanism of ONJ related to therapy directed to the bones. More studies focused on this subject are required. It is recommended that patients who are going to receive Denosumab have a dental evaluation before starting treatment. ${ }^{6,7}$

A meta-analysis was conducted that included a total of 7 prospective clinical trials, with a total of 8963 patients, comparing the role of osteosclerosis of the jaw of Denosumab and bisphosphonates, with an average treatment time of 7-20 months. The use of this drug significantly increased the risk of developing the disease (RR 1.613), with an incidence of $1.7 \%$. 6

The recommended dose of Denosumab is $120 \mathrm{mg}$ sc on day 1,8 , 15,29 and then 4 weekly. ${ }^{1}$ Another of the recommended schemes is the administration of $120 \mathrm{mg} \mathrm{sc}$, every 4 weeks, with an additional 120 mg on days 8 and 15 the first month of treatment for a period of 2.5 to 13 months. In patients presenting primary GCT, treatment should be shorter, 3.5 months, and in patients with recurrent GCT, 6-13 months. ${ }^{4}$

\section{CONCLUSION}

In patients with unresectable advanced GCT, radiotherapy and serial embolization provide palliation of symptoms, but long-term response is infrequent and malignant transformation may occur after radiation. This is where systemic therapy with Denosumab becomes important. The objective of this neoadjuvant therapy is to facilitate surgery at a later stage, making intralesional resection technically easier and therefore improving immediate local tumor control. Further prospective studies are needed on the use of Denosumab, to reach a consensus regarding its dosage, estimated time of therapy and safety profiles. The risk of recurrence presented by the GCT treated with Denosumab and then surgery has yet to be defined. For GCT with surgical contraindication, Denosumab therapy may even be required for life.

All authors declare no potential conflict of interest related to this article.

CONTRIBUTION OF THE AUTHORS: Each author made significant individual contributions to this manuscript. PLB: RF: Planning the work, bibliographic support control, results control, discussion of the conclusions and final edition; AEB: Discussion of the conclusions and primary edition; MM: Discussion of the conclusions and primary edition; NMC: Techical details, discussion of the conclusions and primary edition; SD: Patient oncologist, final editions

\section{REFERENCES}

1. Ng VY, Davidson DJ, Kim EY, Pollack SM, Conrad lii EU, Jones RL. The multidiciplinary management of giant cell tumor of bone. Expert Rev Anticancer Ther. 2014;14(7):783-90.

2. Van der Heijden L, Dijkstra S, Blay JY, Gelderblom H. Giant cell tumour of bone in the denosumab era. Eur J Cancer. 2017;77: 75-83.

3. Chawla S, Henshaw R, Seeger L, Choy E, Blay JY, Ferrari S, et al. Safety and efficacy of denosumab for adults and skeletally mature adolescents with giant cell tumour of bone: interim analysis of an open-label, parallel-group, phase 2 study. Lancet Oncol. 2013;14(9):901-8

4. Roitman PD, Jauk D, Farfalli GL, Albergo JL, Aponte-Tinao LA. Denosumab-treated giant cell tumor of bone. Its Histologic Spectrum and Potential Diagnostic Pitfalls. Hum Pathol. 2017:63:89-97.

5. Raskin RA, Schwab JH, Mankin HJ, Springfield DF, Hornicek FJ. Giant Cell Tumor of Bone. J Am Acad Orthop Surg. 2013;21(2):118-26.
6. Qi WX, Tang LN, He AN, Yao Y, Shen Z. Risk of osteonecrosis of the jaw in cancer patients receiving denosumab: a meta-analysis of seven randomized controlled trials. Int J Clin Oncol. 2013:19(2):403-10.

7. Ruggiero S. Osteonecrosis of the jaw: BRONJ and ARONJ. Faculty Dental Journal. 2014;5(2):90-3.

8. Hanley DA, Adachi JD, Bell A, Brown V. Denosumab: mechanism of action and clinical outcomes- Ahmed. Int J ClinPract. 2012;66(12):1139-46.

9. Turner B, Ali S, Drudge-Coates L, Pati J, Nargund V, Wells P. Skeletal Health Part 1: Overview Of Bone Health and Management In the Cancer Setting. Urol Nurs. 2016;36 (1):17-21.

10. Thomas D, Henshaw R, Skubitz K, Chawla S, Staddon A, Blay JY, et al. Denosumab in patients with giant-cell tumour of bone: an open-label, phase 2 study. Lancet Oncol. 2010;11(3): 275-80 